\title{
A legeltetés hosszú távú hatásai a kiskunsági füves pusztákon
}

\author{
Kiss Tímea és Penksza Károly² \\ ${ }^{1}$ Neumann János Egyetem, 6000 Kecskemét, Mészöly Gy. tér 1-3 \\ ${ }^{2}$ Szent István Egyetem 2100 Gödöllö, Páter K. u. 1. \\ e-mail:kiss.timea@kvk.uni-neumann.hu
}

\begin{abstract}
Összefoglaló: A vizsgálatok a Kiskunságban, a Bugac település melletti száraz gyepi legelőn és a Tatárszentgyörgy település melletti nedves legelön történtek. A cönológiai felvételek három zónában készültek. Az első zónába az állattartó telephez közeli 0-50 m-re („A” zóna), a második zónába az állattartó teleptől 50-150 m-re („B” zóna), a harmadik zónába az állattartó teleptől több, mint 150 m-re („C” zóna) található kvadrátok tartoztak. Eredményeink alapján a többi felvételtől jól elkülönültek a karámhoz közeli "A” zóna kvadrátjai. A vizsgálati években itt volt a legalacsonyabb a fajszám és a diverzitás. A bugaci területen a „C" zóna diverzitás értéke nőtt a vizsgált időszakban, azonban még mindig elmaradt a „B” zónától. A nedves fekvésủ tatárszentgyörgyi gyepben a természetvédelmi értékeket is megőrző gyepösszetétel kialakulása a karámtól távolabb lévő területen („C” kategória), a kisebb legeltetési nyomás mellett valósult meg.
\end{abstract}

Kulcsszavak: legeltetés, állattenyésztés, természetvédelem, cönológiai vizsgálat, legelő.

\section{Bevezetés}

A Pannon biogeográfiai régiónak az Alföld területén jellegzetes vegetáció típusai alakultak ki. Ezek közül számos élőhely, társulás fennmaradásáért évszázadok óta az emberi tevékenység a felelős. A Duna-Tisza közén mozaikos megjelenésü nagy kiterjedésü gyepek találhatók (Kárpáti \& Takács 2008). Magyarországon az országos jelentőségü védett területek nagy részét a különböző gyeptípusok teszik ki, tehát a gyepeknek nem csak a gyepgazdálkodási szerepük nagy, hanem a természetes vegetáció megőrzőjeként is fontosak. Megfelelő természetvédelmi célú kezelésük rendkívül fontos, mivel gazdasági hasznosításuk mellett diverzitásuk megőrzése is feladat (Penksza et al. 2009).

Az extenzív állattartás végigkísérte történelmünket, sőt már a honfoglalás előtti időktől jellemezte a magyarokat. Az ősi paraszti gazdálkodás szerves részét képviselte a legeltetéses állattartás. A 19. században már megjelennek a gyeptelepítésekre és gyepjavításokra vonatkozó rendeletek is (Herman 1909, Dorner 1928). 
Az extenzív hasznosítási módok kulcsfontosságú szerepet játszanak az élőhelyek természetes értékeinek megörzésében (Sutcliffe et al. 2015). A legeltetés (kaszálás) szükséges a fajok gazdag élőhelyeinek fenntartásához (Middleton 2013).

A cönológiai felvétek eredményeivel és azok értékelésével adunk adatokat a legeltetés intenzitásától függő vegetációbeli változásokhoz.

A mintavételi területek az Alföldön találhatók, annak is azon a területein ahol a legeltetéses állattartásnak komoly hagyományai vannak. A kiválasztott gyepek további közös ismérve, hogy természeti oltalom alatt álló területeken helyezkednek el a Kiskunsági Nemzeti Park területén.

A vizsgálatok elsősorban arra irányultak, hogy történtek-e változások a vegetációban a vizsgált időszakban. Kérdés volt továbbá, hogy az adott kezelés megfelel-e a közepes diszturbancia hipotézisének, vagyis a zavarás mértéke mellett a vizsgált életközösségben a legnagyobb diverzitási szint alakult-e ki.

\section{Anyag és módszer}

\section{Mintavételi területek:}

A mintavételi területek a Pannon biogeográfiai régióban a Duna-Tisza köze középtáj területén (Marosi \& Somogyi 1992), Bugac és Tatárszentgyörgy térségében, a településektől dél-nyugatra találhatók. A bugaci terület egy száraz fekvésü gyepi rész, a tatárszentgyörgyi pedig egy nedves fekvésủ gyep terület. A bugaci legelőn 1990 óta csak legeltetést folytatnak (a területen gazdálkodók szóbeli közlése alapján). 2000-ig szabad legeltetést alkalmaztak, majd 2000 után szakaszoltatást végeznek. A területen szarvasmarha és juh legel. A gyep terhelése egységesen 0,4 számos állat/ha. Megfigyeléseink alapján, az állatok a „B” és a „C” zónában legelnek, itt töltik a legelési idő jelentős részét. Azonban a kihajtás/behajtás során az „A” zóna kapja a legnagyobb terhelést.

A tatárszentgyörgyi mintaterület mélyebben fekvő, a Deschampsenion caespitosae asszociációcsoportba sorolható (Borhidi 2003) mocsárrét (AgrostioDeschampsenion caespitosae) (Ujvárosi 1947) társulással. A területet csak szarvasmarhával legeltetik, szabad legeltetést alkalmazva. A gyep terhelése a bugaci területhez hasonlóan, egységesen 0,4 számos állat/ha.

\section{Cönológiai felvételezések}

A bugaci felvételeket 1997, 2005 és 2017 júniusában készítettük. A tatárszentgyörgyi felvételeket 2007, 2008, 2009 és 2010 júniusában. A felvételezéshez Braun-Blanquet (1964) módszerét követtük, $2 \times 2$ m-es kvadrátokat alkalmazva, de a borítási értékeket minden fajhoz százalékban kifejezve adtuk meg. 
Ugyanakkor minden szint borítási értékét külön vettük fel. A fajnevek Simon (2000) nómenklatúráját követik.

A legeltetési nyomás, a gyephasználat intenzitásának, a vegetáció változásának nyomon követésére, a karámtól távolodva három szakaszra, zónára (területi sáv) osztottuk a növényzetet: „A” zóna: 0-50 m, a legnagyobb mértékủ zavarás és taposás figyelhető meg. „B” zóna: 50-150 m között szakaszon közepes zavarás érvényesül. „C” zóna: 150 m-nél távolabb a zavarás elhanyagolható mértékü.

A bugaci területen a rendelkezésre álló legelő terület a zónákra merőlegesen három szakaszra van felosztva. Az egyes szakaszokban az állatok 14 napot legelnek. A tatárszentgyörgyi területnél a gazdasághoz tartozó legelőt villanypásztorral kerítették körbe így az állatok ember (pásztor) felügyelete nélkül szabadon legelnek.

\section{Az adatok feldolgozása}

A cönológiai adatok feldolgozásakor a fajszámok megadása és a diverzitás kiszámítása alkalmával a teljes felvételezési táblázatot használtuk, Bugac és Tatárszentgyörgy esetében is az összes év adatait felhasználva. Azon fajokat, amelyek csak ritkán fordultak elő és borítási értékük is $1 \%$ alatt volt, elhagytuk a klasszifikációs elemzések alkalmával, ekkor csak a diagnosztikai (társulásokra jellemzö) fajokat vizsgáltuk. A statisztikai elemzések során normális eloszlású modelleket állítottunk fel, melyekben függő változóként szerepelt a fajszám, magyarázó változóként pedig az SHDI érték és a transzszektek széli vagy belső helyzetét jelző transzszekt-pozíció érték. Random faktorként vettük be a modellbe a gazdálkodó, valamint a terület hatását.

Kiszámoltuk az egyes területekre jellemzö átlagos fajszámot és Shannondiverzitás értékét (Pielou 1975). Post hoc tesztként a Tukey HSD eljárást alkalmaztuk, amely korrigált $p$ értéket ad, így a Bonferroni korrekció elvégzése szükségtelenné válik.

Az egyes felvételek Shannon-diverzitásának kiszámolása után az egyes területek átlagát vettük, ezeket hasonlítottuk össze a növekvő zavarás mellett mindkét területen. Az átlagos diverzitásértékek kiszámolásán túl többletinformációt jelent az egyes típusok diverzitás profiljának megrajzolása. Ezt a Rényi-diverzitással tettük meg (Tóthmérész 1995). Ebben a vizsgálatban az egyes éveket összevonva csak a helyek és a területek közötti különbséget értékeltük. 


\section{Eredmények}

Fajösszetétel, vegetációelemzés, fajdiverzitás

A fajok a bugaci és tatárszentgyörgyi területenkénti és zónánkénti, kezelési típusonkénti megoszlása szerint (Borhidi 1995-ös kategóriáit használva) az „,A” zóna felvételeinek fajai közül három volt gyom, amelyek csak itt fordultak elő. Mindkét legelő „A” zónájában megjelenik a Poa humilis. Azon fajok közül, amelyek általánosan minden területen, és ezen belül is az „A”, a „B” vagy a „C ” zónában is megtalálhatók, csak egy, Simon (2000) szerint a természetes vegetációra jellemző faj volt jelen: az Achillea asplenifolia. Ugyanakkor Borhidi (1995) ezt zavarástürőnek tekinti. A zónáktól és a vizsgálati helyszínektől függetlenül előforduló fajok közül tíz volt gyom. A többi faj (47\%), pedig zavarástürő. Azon fajok között, melyek mindkét mintaterületen előfordulnak, jelentős arányban vannak jelen a természetes gyepek fajai. A közös fajok közül a természetes gyepek alkotóelemei a tatárszentgyörgyi mintaterületen mutatnak nagyobb borítási értékeket.

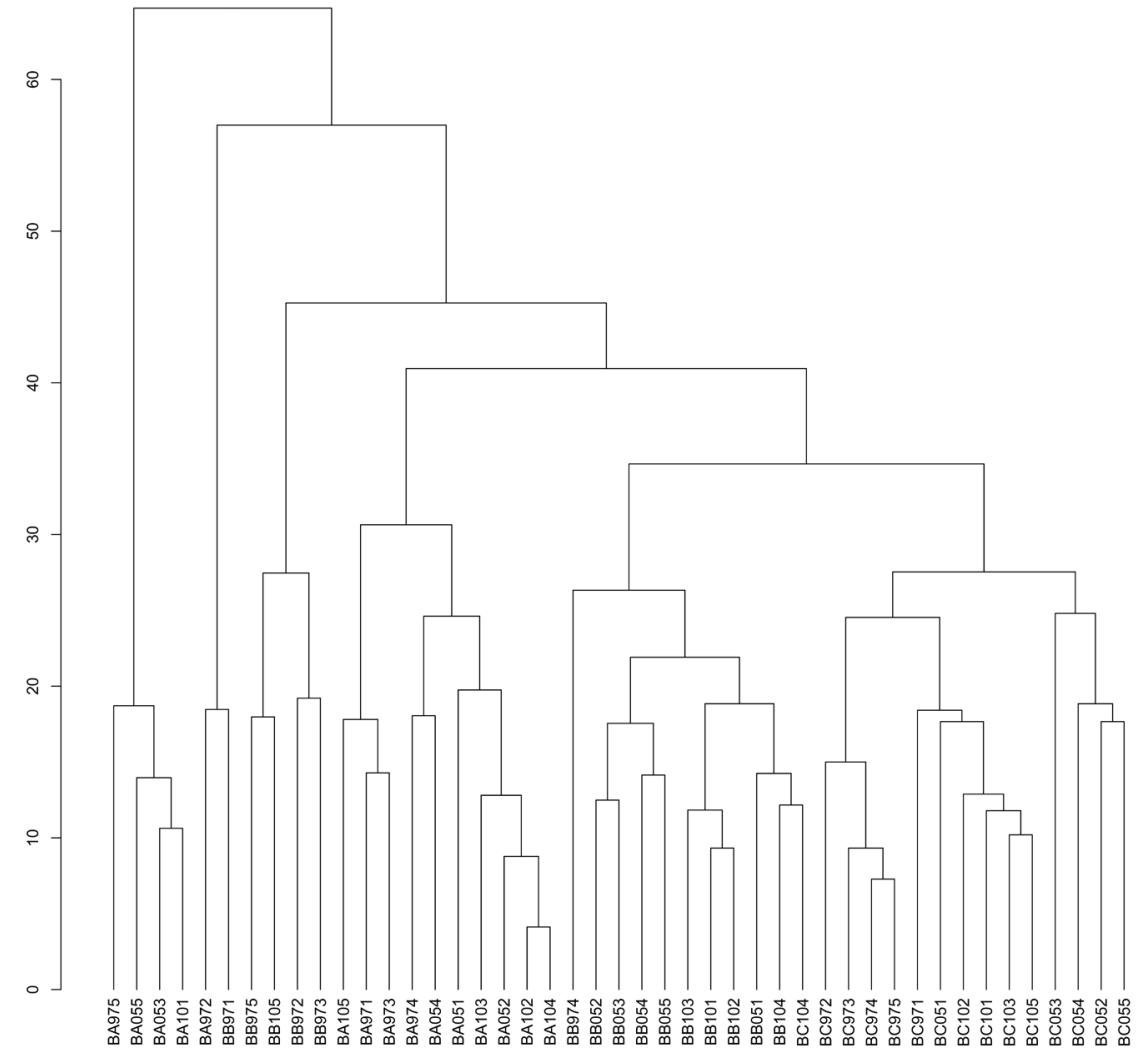

1. ábra: A bugaci területek cönológiai eredményeinek klasszifikációja 
A bugaci terület esetében a klaszterelemzés során a karámhoz közeli („A”) cönológiai felvételek keverednek a „B” 1997-es felvételekkel, melyek egységes csoportként ékelődnek be. A „B” és a „C" zónák mintanégyzetei is keverednek egymással (1. ábra).

A tatárszentgyörgyi felvételeket elemezve a két utas klaszteranalízis határozottan elkülöníti a karámhoz közeli, „A” zónák cönológiai felvételeit. A „B” területi sávok felvételei is egy tömbben jelennek meg. A „C” csoportba tartozó kvadrátok cönológiai felvételei kettéválva alkotnak egységeket (2. ábra).

A bugaci és tatárszentgyörgyi cönológiai felvételeket tartalmazó klasszifikáció eredményei alapján a karám közeli „A” csoport felvételeinek nagy része már 0,8 különbözőségi szinten elkülönül. A többi „A” zónához tartozó felvételek is

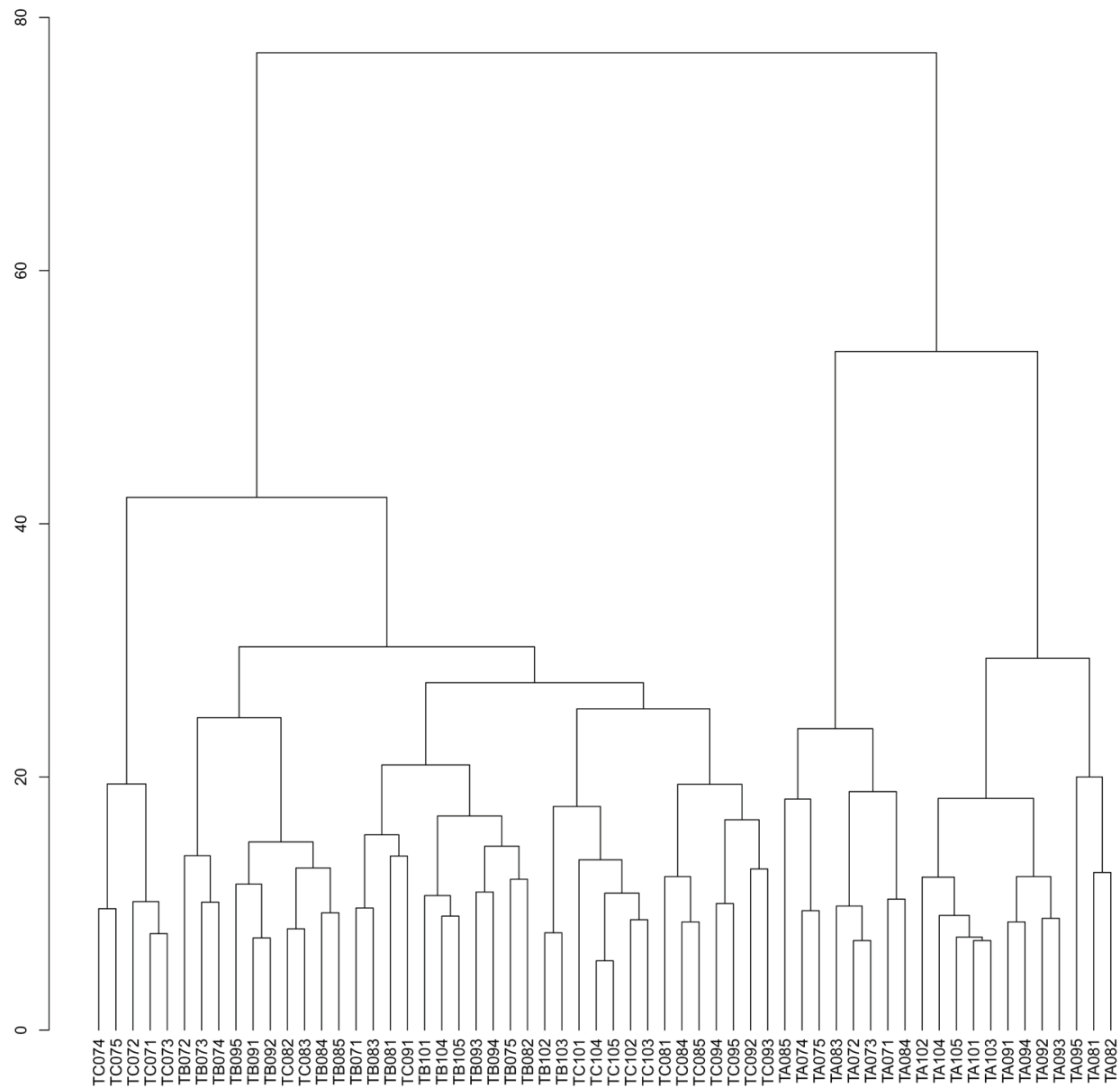

2. ábra: A tatárszentgyörgyi területek cönológiai eredményeinek klasszifikációja 
nagy különbözőségi szinten válnak el. A dendogram szerint 0,42 körüli különbözőségi szinten két nagy csoport különíthető el. Ebből a kisebb halmaz elsősorban a bugaci „B” zónák felvételeit tartalmazza, a nagyobb csoport a bugaci és a tatárszentgyörgyi „B” „C” területi sávok kvadrátjait foglalja magába.

A bugaci és a tatárszentgyörgyi területek fajszámainak alakulása (1-2. táblázat): a legnagyobb teljes előforduló faj szám a bugaci „B” zónában volt, de a bu1. táblázat: A bugaci cönológiai felvételek teljes fajkészlete a vizsgált években, a „B” és „C" területek fajszámai éves bontásban

\begin{tabular}{lcccc}
\hline & 1997 & 2005 & 2017 & fajkészlet \\
\hline Bugac A & & & & 33 \\
\hline Bugac B & 38 & 36 & 28 & 52 \\
Bugac C & 37 & 41 & 39 & 48 \\
\hline
\end{tabular}

2. táblázat: A tatárszentgyörgyi cönológiai felvételek teljes fajkészlete a vizsgált években, a „B” és „C” területek fajszámai éves bontásban

\begin{tabular}{lccccc}
\hline & 2007 & 2008 & 2009 & 2010 & fajkészlet \\
\hline Tatárszentgyörgy A & & & & & 23 \\
Tatárszentgyörgy B & 28 & 32 & 30 & 30 & 39 \\
Tatárszentgyörgy C & 28 & 27 & 32 & 38 & 38 \\
\hline
\end{tabular}

gaci „C" zóna is nagyobb fajszámmal rendelkezett a tatárszentgyörgyi „C” területi sáv felvételeihez képest. Bugacon az éves bontás alapján, a teljes fajszám esetében folyamatos csökkenés látható, azonban csak a „C” zónát kiemelve fajszám növekedés mutatkozik.

A Shannon-diverzitás értékeit kiszámolva megállapítható, hogy a bugaci területen a diverzitás a karámhoz közeli „A” zónában jelentősen nem változott a vizsgált időszakban (3. táblázat). A diverzitási érték az istállótól távolodva nőtt a 3. táblázat: A bugaci terület zónáinak $(A, B, C)$ diverzitási értékei

\begin{tabular}{llll}
\hline & 1997 & 2005 & 2017 \\
\hline Bugac A zóna & 2,15 & 2,41 & 2,30 \\
Bugac B zóna & 2,48 & 2,97 & 3,18 \\
Bugac C zóna & 2,89 & 2,92 & 3,25 \\
\hline
\end{tabular}

vizsgált időszakban, ez mind az 50-150 m-es „B” területi sáv kvadrátjaira, mind a legtávolabbi „C” zónában jellemző volt. A tatárszentgyörgyi területen a karámhoz közeli „A” zónában az első két évben (2007-2008) viszonylag magas a diverzitás. A 2009 és 2010-es években hirtelen lecsökken. A középső „B” területeken a vizsgált négy év alatt a diverzitás szinte állandó, a legtávolabbi „C” zónában kezdetben közepes, majd a következő három évben magas lesz (4. táblázat). 
4. táblázat: A tatárszentgyörgyi terület zónáinak $(A, B, C)$ diverzitási értékei

\begin{tabular}{lllll}
\hline & 2007 & 2008 & 2009 & 2010 \\
\hline Tatárszgyörgy A zóna & 2,03 & 2,10 & 1,32 & 1,03 \\
Tatárszgyörgy B zóna & 2,79 & 2,90 & 2,80 & 2,95 \\
Tatárszgyörgy C zóna & 2,42 & 2,92 & 2,75 & 3,01 \\
\hline
\end{tabular}

Rényi diverzitási profilok

A bugaci területen a három zavarási típus jól elkülönül a Rényi-diverzitási profil segítségével. A leginkább zavart „A” zóna görbéje rendelkezik végig a legalacsonyabb diverzitási értékekkel, a „B” és „C” területi sávok görbéje kezdetben együtt halad, diverzitásuk azonos, később a nagyobb alfa értékeknél szétválik (3. ábra). A tatárszentgyörgyi terület esetében a „C” zóna (a legkevésbé zavart terület) diverzitása lesz a legmagasabb (4. ábra).

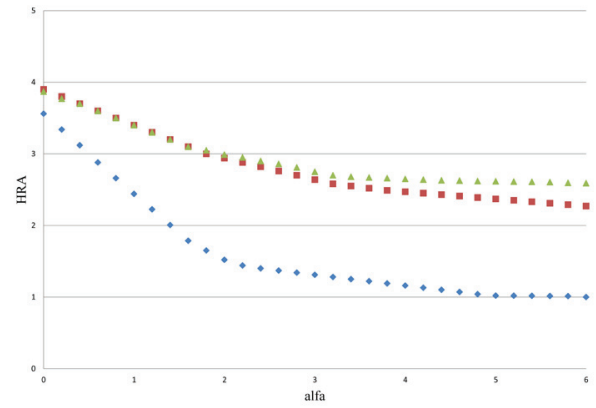

3. ábra: A bugaci terület Rényi-diverzitás profilja (A, B és C zóna)

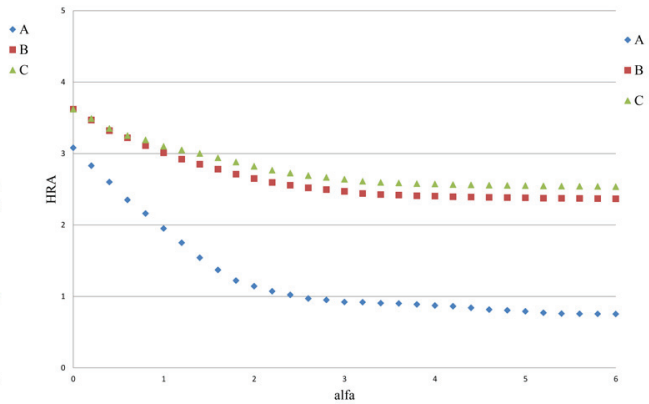

4. ábra: A tatárszentgyörgyi terület Rényi-diverzitás profilja (A, B és C zóna)

Következtetések, javaslatok

A karámhoz közeli zóna („A”) elsősorban gyom fajokban gazdag, ami az erős túllegeltetés és a jelentős taposás következménye, hasonlóan Wilson \& MacLoad (1991) megállapításával is. A pázsitfü fajok közül a Poa humilis is csak itt, a túllegeltetett és taposott területeken fordul elö. Ez a faj, - hasonlóan több pannon túllegeltetett térszínhez (Szentes et al. 2007, Penksza et al. 2009) - a túllegeltetés indikátorfajaként is figyelembe vehető, ugyanakkor ruderális területeken szintén jellemző. Indikátor voltát a jelen vizsgálati sor is megerösíti.

A cönológiai felvételekben az általánosan előforduló fajok - melyek kb. a diagnosztikai fajok negyedét jelentik - gyomok vagy zavarástürők, amelyek egyértelmüen zavart területek növényzetét mutatják (Simon 1988). Ezek előfordulása az „A" zónában jelentős. A távolabbi, „B” és „C” zónákban főleg a bugaci száraz fekvésủ gyepben, homoki legelön és a tatárszentgyörgyi nedves fekvésủ térszínen 
a természetes vegetáció a jellemző. Ezekben a zónákban az általánosan előforduló fajokon kívül a gyomok és a zavart területek fajainak aránya kicsi. A legeltetés a területek fajösszetételét ugyan kis mértékben, de pozitív irányba alakította át. Változás a vegetációban a karámközeli területi sávokban figyelhető meg. Számos munkával párhuzamosan (Catorci et al. 2012, Tóth et al. 2003, Noy-Meir et al. 1989, Fernández-Alès et al. 1993, Hadar et al. 1999; Szentes et al. 2007; Házi et al. 2011) megerősítette a vizsgálat, hogy a legeltetés a legelő fajösszetételére és fajszámára kedvezően hat.

A bugaci területeken a diverzitási értékek az istállótól távolodva nőttek a vizsgált időszakban. Hasonló következtetésre jutunk a fajszámok alakulásának vizsgálatával. Nagymértékü zavarás esetén („A” zóna) a sztochasztikus folyamatok kerülnek előtérbe, kisebb a rendezettség és kevésbé megjósolható a fajszámok alakulása, illetve a mért adatok erősen szórnak (Házi et al. 2011, Tóthmérész 1995). Arra a kérdésre, hogy vannak-e olyan területrészek, ahol a kezelés eleget tesz a természetvédelmi igényeknek, a jelen vizsgálat ad választ. Az „A” zónák természetvédelmi értékelés során átalakított, gyomokban és zavarástürőkben gazdag térszínt mutatnak, hasonlóan más pannonlegelők karámközeli területeihez (Penksza et al. 2009). A szárazabb gyepben (Bugac) az erőteljesebb legeltetés a karámhoz közeli „B” zónában természetvédelmi szempontból is értékesebb vegetáció kialakulásához vezetett. A „C” zóna diverzitás értéke nőtt a vizsgált időszakban. A nedves fekvésủ tatárszentgyörgyi gyepben a jelen minta alapján a természetvédelmi értékeket is megőrző gyepösszetétel kialakulása a karámtól távolabb lévő kategóriákban kisebb legeltetési nyomás mellett valósult meg.

Köszönetnyilvánítás - A kutatást a Gödöllői Természetkutató Egyesület és az OTKA K-125423 pályázat támogatta.

\section{Irodalomjegyzék}

Barcsák, Z. \& Kertész, I. (1986): Gazdaságos gyeptermelés és hasznositás. - Mezőgazdasági Kiadó, Budapest, $260 \mathrm{p}$.

Béri, B., Vajna, T.-né. \& Czeglédi, L. (2004): Védett természeti területek legeltetése. - In: Nagy, G.,\& Lazányi, J. (szerk.): Gyepek az agrár-és vidékfejlesztési politikában. DE ATC AVK Vidékfejlesztési és tájhasznosítási Tanszék, Debrecen, pp. 50-58.

Bodó I. (1997): A legeltetés jelentősége a géntartalékok fenntartásában. - In: Nagy, G. \& Vinczeffy, I. (szerk.): Többirányú gyephasználat szaktanácsadási alapjai 1.: legeltetéses állattartás. - Debreceni Gyepgazdálkodási Napok 14., Debrecen, pp. 77-80.

Borhidi, A. (1995): Social behaviour types, the naturalness and relative ecological indicator values of the higher plants in the Hungarian flora. - Acta. Bot. Hung. 39: 97-181.

Borhidi, A. (2003): Magyarország növénytársulásai. - Akadémiai Kiadó, Budapest, 610 p. 
Braun-Blanquet, J. (1964) Pflanzensoziologie, Grundzüge der Vegetationskunde. 3rd Edition Springer-Verlag, Berlin, 631 pp. doi: https://doi.org/10.1007/978-3-7091-8110-2

Catorci, A., Ottaviani, G., Ballelli, S., \& Cesaretti, S. (2011): Functional differentiation of central apennine grasslands under mowing and grazing disturbance regimes. - Pol. J. Ecol. 59: 115-128.

Dorner, B. (1928): A rétek és legelök müvelése és termésfokozása. - Anthaneum, Budapest, 360 p.

Fernández-Alès, R., Laffarga, J.M.,\& Ortega, F. (1993): Strategies in Mediterranean grassland annuals in relation to stress and disturbance. - J. Veg. Sci. 4: 313-322. doi: https://doi. org $/ 10.2307 / 3235589$

Figeczky G. (2004): A legeltetéses állattartás szerepe és helyzete napjainkban. - WWF-füzetek 24., WWF Magyarország, Budapest, 32 p.

Hadar, L., Noy-Meir, I., \& Perevolotsky, A. (1999): The effect of shrub clearing and grazing on the composition of a Mediterranean plant community: functional groups versus species. $-J$. Veg. Sci. 10: 673-683. doi: https://doi.org/10.2307/3237082

Házi, J., Bartha, S., Szentes, Sz., Wichmann, B.,\& Penksza, K. (2011): Seminatural grassland management by mowing of Calamagrostis epigejos in Hungary. - Plant Biosyst. 145: 699-707. doi: https://doi.org/10.1080/11263504.2011.601339

Herman O. (1909): A magyarok nagy ösfoglalkozása. Elötanulmányok. - Hornyánszky Nyomda, Budapest, $430 \mathrm{p}$.

Marosi, S.,\& Somogyi, S. (1990): Magyarország kistájainak katasztere I. - MTA FKI, Budapest, $1024 \mathrm{p}$.

Middleton, Beth A. (2013): Rediscovering traditional vegetation management in preserves: Trading experiences between cultures and continents. - Biol. Conserv. 158: 271-279. doi: https://doi. org/10.1016/j.biocon.2012.10.003

Noy-Meir, I., Gutman, M., \& Kaplan, Y. (1989): Responses of mediterranean grassland plants to grazing and protection. - J. Ecol. 77: 290-310. doi: https://doi.org/10.2307/2260930

Penksza, K., Szentes, Sz., Házi, J., Tasi, J., Bartha, S., \& Malatinszky, Á. (2009): Grassland management and nature conservation in natural grasslands of the Balaton Uplands National Park, Hungary. - In: Nedelník, J., Macháč, R., \& Cagaš, B. (szerk.) Alternative Functions of Grassland: Proceedings of the 15th Symposium of the European Grassland Federation. LPM TISK, Prague, pp. 512-515.

Pielou, E.C. (1975): Ecological diversity. - John Wiley \& Sons Inc, New York, 176 p.

Simon, T. (1988): A hazai edényes flóra természetvédelmi értékének becslése. - Abstr. Bot. 12: 1-23.

Simon, T. (2000): A magyarországi edényes flóra határozója. - Tankönyvkiadó, Budapest, 976 p.

Sutcliffe, L. M. E. et al. (2015): Harnessing the biodiversity value of Central and Eastern European farmland. - Divers. Distrib. 21: 722-773. doi: https://doi.org/10.1111/ddi.12288

Szentes, Sz., Kenéz, Á., Saláta, D., Szabó, M., \& Penksza, K. (2007): Comparative researches and evaluations on grassland manegament and nature conservation in natural grasslands of the Transdanubian mountain range. - Cereal Res. Comm. 35: 1161-1164. doi: https://doi.org/10.1556/ CRC.35.2007.2.249

Tóthmérész, B. (1995): Comparison of different methods for diversity ordering. - J. Veg. Sci. 6: 283-290. doi: https://doi.org/10.2307/3236223 


\title{
The long-term impact of grazing in the grassland of Kiskunság
}

\author{
Tímea Kiss ${ }^{1}$ and Károly Penksza ${ }^{2}$ \\ ${ }^{1}$ Neumann János University, H-6000 Kecskemét, Mészöly Gy. sq. 1-3. \\ ${ }^{2}$ Szent István University H-2100 Gödöllö, Páter K. u. 1. \\ e-mail: kiss.timea@kvk.uni-neumann.hu
}

\begin{abstract}
Investigations were carried out in wet and dry pasture: Bugac and Tatarszentgyorgy. Coenological recordings were taken in three zones. The first zone ("A") located 0-50 m near the stable, second zone ("B") located 50-150 m from the stable, while the third zone ("C") located farther than 150 $\mathrm{m}$. We have carried out analyses of ecological and environmental factors and life form types. Based on our results for both dry and wet grasslands, quadrates of " $\mathrm{A}$ " zone were well isolated from the rest of the zones. Overgrazing, which involves considerable trampling, vanishes differences among vegetations, thereby promotes weed and disturbance tolerant rich vegetation. The lowest species number and diversity could be found here. Because of the change in management, conservation and diversity values of "C" zone increased, however, according to nature protection values it underperformed compared to "B" zone. According to the sample area, wet grasslands from the sandy areas of Kiskunság, preserve nature protection values and grass composition better moving away from stables, due to less grazing pressure. Drier backgrounds tolerate stronger grazing pressure.
\end{abstract}

Keywords: grassland management, nature conservation, coenological research, grazing, pasture 